\title{
内分泌疾患 成人成長ホルモン分泌不全症の診断と治療
}

\author{
肥塚 直美
}

〔日内会誌 $96 ： 1230 １ 234 ， 2007 〕$

はじめに

最近メタボリック症候群に類似している病態 として“成人成長ホルモン分泌不全症”が注目 されている.この病態は成長ホルモン $(\mathrm{GH})$ の 補充により改善がみられ,わが国では 06 年 4 月 より GH治療が可能となった. 本稿では本症につ いてその診断と治療の手引きを紹介し, その活 用の実際について概説する.

\section{成人 $\mathrm{GH}$ 分泌不全症の病態}

GHは成長促進作用のみならず, 蛋白, 糖, 脂 質, 骨, 水電解質代謝, 更に, 免疫系などに多 彩な作用を有するが，小览における成長促進作 用のみが注目されてきた. GH分泌は加齢に伴い 減少するとはいえ, 60 歳以上でも思春期前の $25 \%$ 程度の分泌が認められ, 成人における $\mathrm{GH}$ 役割 が推察されていた．欧米において成人における GH分泌不全症 (成人 GHD) では心・血管系の死 亡率が高いとの報告 ${ }^{1)}$ 以来, 成人 GHDの病態に関 して精力的に研究され, 成人 GHDの症候として, 1) 体組成の異常（循環血漿量低下, 体脂肪増加 (内臟脂肪型肥満), 除脂肪体重減少, 筋肉量低 下, 骨塩量低下)，2）代謝障害（耐糖能異常, 高脂血症, 高血圧, 骨粗鬆症, 動脈硬化症)，3） QOL低下（体力・運動力低下, 情緒不安, エネ

ひづか なおみ: 東京女子医科大学内分泌センター内科
ルギー低下）があげられている．これらの症候 がいわゆるメタボリック症候群と類似している.

成人GHDには発症時期により小児期発症と成 人期発症とに分類され, またGH分泌不全の程度 により重症型（完全型）と中等症型に分類され る. 病因として視床下部あるいは下垂体に器質 的病変の認められる器質性と, 原因が明らかで はない特発性, 遺伝子異常の遺伝性に分類され るが, 特発性成人GHDの存在に関しては論議さ れている.

わが国における本症の発症率は欧米とほぼ同 程度であり, 1 年間当たり 1,200 人の新規患者が 発生し ${ }^{2)}$, 患者総数は約 36,000 人と推定されてい る.

成人GHDの診断と治療のガイドライン

成人GHDの診断および治療に関しては国際的 にはGH Research Society（GRS）のガイドライ ン゙)があり,わが国においてはこれらをふまえ厚 生労働省間脳下垂体機能障害調査研究班により 診断と治療の手引きが作成され，2005 年度に表 に示すように改訂されている ${ }^{4)}$. 米国内分泌学会 も2006 年に診断と治療のガイドラインを作成し ている5). GRSでは本年 3 月にConsensus Meetingを行い, ガイドラインの見直しを行ったので, 本年度中には新しいガイドラインが出される予 定である.

わが国の診断と治療の手引きにそって, その 活用と注意点について述べる. 
表. 成人成長ホルモン分泌不全症の診断と治療の手引き（文献 4 より抜粋）

成人成長ホルモン分泌不全症の診断の手引き

I . 主症候および既往歴

1. 小児期発症では成長障害を伴う.

2. 易疲労感，スタミナ低下，集中力低下，気力低下，うつ状態，性欲低下などの自覚症状を伴うことがある，

3. 身体所見として皮膚の乾燥と菲薄化, 体毛の柔軟化, 体脂肪（内臟脂肪）の増加，ウェスト比ップ比の増加，除脂肪体重の低 下，骨量の低下，筋力低下などがある.

4. 頭蓋内器質性疾患の合併ないし既往歴, 治療歴または周産期異常の既往がある.

II. 検查所見

1. 成長ホルモン $(G H)$ 分泌刺激試験として, インスリン負荷, アルギニン負荷, L-DOPA 負荷, グルカゴン負荷, または GHRP2 負荷試験を行い，下記の值が得られること：インスリン負荷。アルギニン負荷. L-DOPA 負荷またはグルカゴン負荷試験に おいて, 負荷前および負荷後 120 分間（グルカゴン負荷では 180 分間）にわたり, 30 分ごとに測定した血清（血漿） GH の頂值が $3 \mathrm{ng} / \mathrm{ml}$ ( リコンビナント GH を標準品とする GH測定法) 以下である. GHRP-2 負荷試験で, 負荷前および負荷 後 60 分にわたり，15 分毎に測定した血清（血漿） GH 頂值が $9 \mathrm{ng} / \mathrm{ml}$ (リコンビナント $\mathrm{GH}$ を標準品とする $\mathrm{GH}$ 測定法) 以下である時, インスリン負荷における $\mathrm{GH}$ 頂值 $1.8 \mathrm{ng} / \mathrm{ml}$ （リコンビナント $\mathrm{GH}$ を標準品とする $\mathrm{GH}$ 測定法）以下に相当 する低 $\mathrm{GH}$ 分泌反応であるとみなす.

2. GH を含めて複数の下垂体ホルモンの分泌低下がある.

II. 参考所見

1. 血清（漿）IGF-I 值や血清IGFBP-3 值が年齢および性を考慮した基準值に比べ低值である.

2. 堅機能が正常な場合で, 2 〜 日間測定した 24 時間尿または夜間入眠から翌朝起床までの尿中 $G H$ 排泄量が正常值に比べ低 值である.

[判定基準]

成人成長木ルモン分泌不全症

1. I の 1 あるいは I の 2 と 3 を満たし，かつ】の 1 で 2 種類以上の $\mathrm{GH}$ 分泌刺激試験において基準を満たすもの.

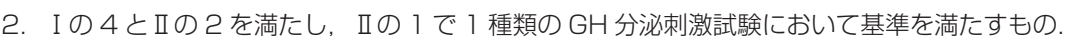

GHRP-2 負荷試験の成績は, 重症型の成人 GH 分泌不全症の判定に用いられる（注 8).

成人成長木ルモン分泌不全症の疑い

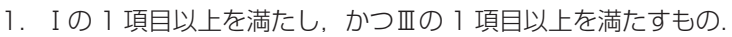

[病型分類 $]$

重症成人成長木ルモン分泌不全症

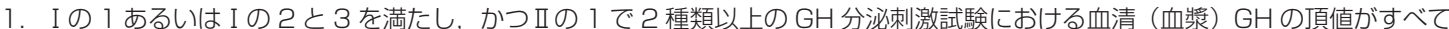
$1.8 \mathrm{ng} / \mathrm{ml}$ 以下 (GHRP-2 負荷試験では $9 \mathrm{ng} / \mathrm{ml}$ 以下) のもの. 血清（血漿） $\mathrm{GH}$ の測定は,リコンビナント GH を標準品と する GH 測定法による。

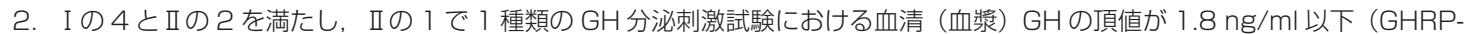
2 負荷試験では $9 \mathrm{ng} / \mathrm{ml}$ 以下）のもの．血清（血漿）GH の測定は，リコンビナント GH を標準品とする $\mathrm{GH}$ 測定法による.

中等度成人成長木儿モン分泌不全症

成人 $G H$ 分泌不全症の判定基準に適合するもので，重症成人 $G H$ 分泌不全症以外のもの.

（附 1）下垂体性小人症，下垂体性低身長症または $\mathrm{GH}$ 分泌不全性低身長症と診断されて $\mathrm{GH}$ 投与による治療歴が有るものでも，成 人において GH 分泌刺激試験に正常な反応を示すことがあるので再度検査が必要である。

(附 2）成人において $\mathrm{GH}$ 単独欠損症を診断する場合には，2 種類以上の $\mathrm{GH}$ 分泌刺激試験において，基準を満たす必要がある。

成人成長木ルモン分泌不全症の治療の手引き

I 治療の基本

GHだけでなく，他の欠乏しているホルモンの補充療法が必要である.

治療の目的は, $G H$ 分泌不全に起因すると考えられる易疲労感, ス夕ミナ低下, 集中力低下などの自覚症状を含めて生活の質 （QOL）を改善し，体脂肪量の増加，除脂肪体重の減少などの体組成異常および血中脂質高值などの代謝障害を是正することである。 GH治療の適応に関して, 成人 $G H$ 分泌不全症と診断された患者のうち重症成人 $G H$ 分泌不全症の診断基準を満たした患者を当面の 対象とする。中等度成人 $\mathrm{GH}$ 分泌不全症患者に対する $\mathrm{GH}$ 治療の適応については今後の検討課題である。一般的に GH治療において

は，糖尿病患者，悪性腫瘍のある患者や妊婦または妊娠している可能性のある女性は禁忌とされている。

I 治療の実際

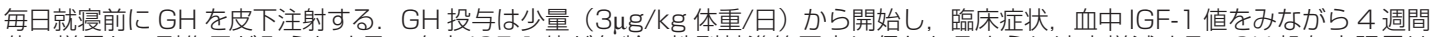
単位で増量し、副作用がみられず且つ血中IGF-1 值が年齢・性別基準範囲内に保たれるように適宜增減する。GH投与上限量は $1 \mathrm{mg} /$ 日とする. GHに対する反応性には個人差が大きいことから, kg 体重当たりで調整するより個体当たりで調整する方が良い亡 する意見もある。

有害事象として GH の体液貯留作用に関連する手足の浮腫，手根管症候群，関節痛，筋肉痛などが治療開始時にみられるが，その

多くは治療継続中に消失する。

治療経過中，定期的に血中 iGF- 7 值を測定し，年齢·性別基準範囲内であることを確認する，体組成の改善。代謝障害の是正, QOL の改善なざ GH 治療の臨床効果を評価する。 


\section{診断}

表の主症候および既往歴を有し, GH分泌刺激 試験でGH分泌不全を認めることにより診断する.

\section{GH分泌刺激試験}

血中GHは脈動的に分泌されており, 健常人で も感度以下の值を示すことがあるので, 血中GH の 1 回の測定のみで健常人とGHDとを区別する ことはできない.そこで, GH分泌動態を評価す るためにGH分泌刺激試験を行う.負荷試験とし てはインスリン低血糖 (ITT), アルギニン, ク ロニジン, グルカゴン, L-ドーパ, GHRH, GHRP2 負荷試験があるが, GHRH, クロニジン負荷試 験はは偽性低反応を呈することがあるので成人 GHDの診断のためには使用しない（新しいGRS のConsensusではアルギニンも本症の診断には推 奨されない検查となった).

負荷試験（GHRP-2 は除く）に対してGHが 3 $\mathrm{ng} / \mathrm{ml}$ (リコンビナント GHを標準品とする GH 測定法*) 以上の増加反応を呈すれば正常である. 成人 GHDでは頂值 $3 \mathrm{ng} / \mathrm{ml}$ 以下の低反応を呈する が, 分泌不全の程度により, GH頂值が $1.8 \mathrm{ng} / \mathrm{ml}$ 以下を重症型 (完全型) GH分泌不全性低身長症, それ以外のものを中等症と分類する. 成人 GHD の検査としてITTが推奨されてきたが, 虚血性心 疾患や痤攣発作を有する症例では禁忌であり，

ITT同等の診断価值のあるものとして, 2005 年より GHRP-2 が使用されている. 重症成人GHD が疑われる場合はITTまたはGHRP-2 負荷をまず 試みることが推奨されている. GHRP-2 負荷の後 のGH頂值が $9 \mathrm{ng} / \mathrm{ml}$ 以下の場合を重症成人 GHD と診断する. GHRP-2 負荷試験はGHの頂值がほ

*2005 年 4 月よりリコンビナント GH（rGH）を標準品 とする $\mathrm{GH}$ 測定法に変更され5), キット間較差はなくなっ たが, GH測定值は従来の值の $60 \%$ となったため, 基準 值が変更された. rGHを標準品とするGH測定法で得ら れる $\mathrm{GH}$ 值 $3 \mathrm{ng} / \mathrm{ml}$ は従来法の $5 \mathrm{ng} / \mathrm{mll}$ 相当する. 本稿 ではすべて rGHを標準品とするGH測定法による值を示 す.
ほ 30 分までに認められ, 45〜60 分で検査が終了 でき, 副作用が少ない点で臨床上有用であるが, 中等度成人GHDの診断の基準值はまだ設定され ていない.

小児期にGH治療を行ったGHDがすべて成人 GHDに該当するのではなく, GH分泌刺激試験を 再度行う必要がある。

\section{IGF-I}

GHの作用を仲介するIGF-I(ソマトメジンC)は 大きな日内変動もなく $\mathrm{GH}$ 分泌動態を反映し, 本 症では血中IGF-I值低值を示すが, 基準值内の症 例も認められるので，診断基準ではなく参考所 見とされている.

\section{他の内分泌検査}

本症ではGH以外に下垂体ホルモン分泌不全も 合併する症例が多いので，これらホルモン分泌 能を検査する。

\section{画像検査}

器質的な原因が疑われる場合には下垂体MRI を行う。

\section{診断の手順}

診断の手引きを基にしたフローチャートを図 に示す。

成人 GHDにおいて注意すべき点は成人の $\mathrm{GH}$ 単独欠損症を診断する場合には，下垂体病変が あっても 2 種類以上のGH分泌刺激試験において 基準を満たす必要がある.

\section{治療}

GHの補充量が行われるが，わが国における GHDのGHの治療適応は小児ではGHD全て(重症 GHDのみならず中等症GHDも含まれる) が対象 であるが，現時点では成人GHDの治療対象は重 症GHDのみが対象である。また，特発性の重症 成人GHDについては現時点でGH治療の保険適応 がとれていないので注意が必要である.

わが国では 2006 年 4 月から治療が可能となっ た．治療の目的は，GH分泌不全に起因すると考 

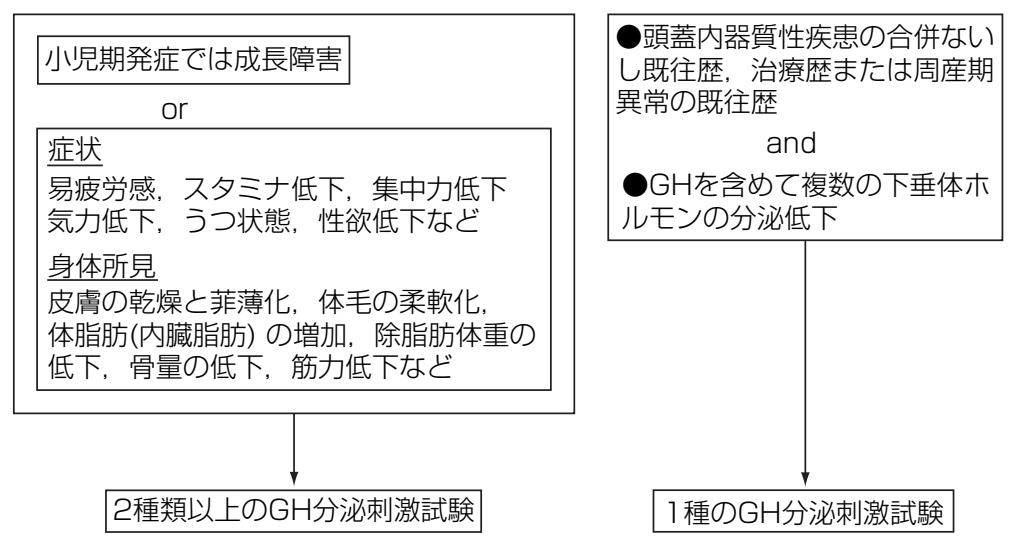

\section{成人 GHD : GH頂值 $\leq 3 \mathrm{ng} / \mathrm{ml}$ \\ 重症成人 GHD：GH頂值 $\leq 1.8 \mathrm{ng} / \mathrm{ml}(\mathrm{GHRP}-2$ では $\leq 9 \mathrm{ng} / \mathrm{ml}$ ) 中等度成人 GHD：GHDのうち重症GHD以外のもの}

図. 成人成長ホルモン分泌不全症の診断のフローチャート

えられる易疲労感, スタミナ低下, 集中力低下 などの自覚症状を含めて生活の質 (QOL) を改 善し, 体脂肪量の増加, 除脂肪体重の減少など の体組成異常および血中脂質高值などの代謝障 害を是正することである．前述したように $\mathrm{GH}$ 治療の適応に関して成人GHDと診断された患者 のうち重症成人GHDの診断基準を満たした症例 が現在の対象である.

$\mathrm{GH}$ の治療の実際は, 毎日就寝前にGHを皮下注 射する. $\mathrm{GH}$ 投与は少量 $(3 \mu \mathrm{g} / \mathrm{kg}$ 体重/日）から 開始し, 臨床症状, 血中IGF-I值をみながら 4 週 間単位で増量し, 副作用がみられず且つ血中IGFI值が年齢・性別基準範囲内に保たれるように適 宜増減する. $\mathrm{GH}$ 投与上限量は $1 \mathrm{mg} /$ 日で, 小児 の投与量と比較すると, 小児では $0.175 \mathrm{mg} / \mathrm{kg} /$ 週，すなわち， $25 \mu \mathrm{g} / \mathrm{kg} /$ 日であり，成人では大 体 6 $8 \mu \mathrm{g} / \mathrm{kg} /$ 日位が多く, 大体小児の $1 / 4$, 多 くても $1 / 2$ 量である.

有害事象としてGHの体液貯留作用に関連する 手足の浮腫, 手根管症候群, 関節痛, 筋肉痛な どが治療開始時にみられるが，その多くは治療 継続中に消失する．治療経過中は定期的に血中 IGF-I值を測定し, 年齢・性別基準範囲内である ことを確認する(血中IGF-Iの測定はGH投与開始
後 24 週目までは 4 週間に 1 回，それ以降は 12 週から 24 週間に 1 回を目安). 体組成の改善, 代謝障害の是正, QOLの改善などGH治療の臨床 効果を評価する，QOLの評価に関しては日本人 下垂体機能低下症患者のQOL評価質問紙(JAHQ) が開発されている.

GHだけでなく他の欠乏しているホルモンの補 充療法が必要であるが, GH補充療法を開始した 際に他のホルモンとの相互作用があるので注意 が必要である. 甲状腺ホルモンについて GH投与 により中枢性甲状腺機能低下症の顕在化や, T4 補充量の増加をきたすことがある。また， GH は11ßHSD-1 の活性を抑制するとの報告があり， 本症にGH治療を行った際に臨床的に副腎不全を きたしやすくなるのかは明らかではないが、コ ルチゾールの補充を行っている症例ではコルチ ゾール補充量の増加が必要であるのか, 注意が 必要である，性ステロイドに関しては，エスト ロゲンを経口的に投与すると肝臓でのIGF-Iを抑 制することから貼付型のエストロゲンに比べて 経口剂では同じGHの効果を得るのにより多くの GHが必要である. GH補充を行う際には貼付型エ ストロゲン製剤が推奨されている，また，GH はテストステロンの作用を増強し, 体液貯留を 
増強させるので同時投与の際には浮腫などが出 やすいとの報告がある.

\section{診断と治療を進めるにあたって}

診断を進めるにあたり, 肥満ことに内臓脂肪 型肥満があり, 易疲労感, スタミナ低下, 集中 力低下などの症状がみられたらまず本症を疑う. 特に, 小児期にGH治療をした既往のある症例や 視床下部・下垂体疾患を中心とする頭蓋内器質 性疾患症例は検査の対象となる。最近では頭部 外傷後およびくも膜下出血後のGHDの発症につ いても報告されており，このような疾患も症状 が認められる場合は検査の対象となる。一般内 科医として本症を疑った場合はまずGHを含めた 下垂体ホルモン系の評価を行う。基礎值のみで は診断するとこはできず，負荷試験が必要であ り，検査の選択や評価など専門性を必要とする ので，疑った場合は内分泌専門医へ紹介するこ とが望ましい.成人GHDのGH治療が認められた ばかりであり，診断，治療が適切に行われるた めに, 一般医家からの相談にのり, 助言するシ ステムとして，成長科学協会に成人成長ホルモ ン分泌不全症委員会を設置し，また，それぞれ の地域に内科, 小児科, 脳外科の領域にまたが る地区委員を設置した（今後, 成長科学協会の ホームページに掲載される予定である).

治療開始にあたっては内分泌専門医のところ で開始されることが望ましいが, 維持投与となっ たところでは, 専門医と連携を持ちながら（定 期的に通院),一般内科医で治療することは問題 ない. その際, 自覚症状を含めて生活の質 $(\mathrm{QOL})$, 体組成異常(簡便には腹囲の測定), 血中脂質高 值などの代謝障害に注目して治療を行う。

GHおよびIGF-Iは細胞増殖作用があることよ り，脳腫瘍の再発および新生物の発生が懸念さ れるが, 現在のところGH治療による脳腫瘍再発 率の増加および新生物発生の増加は認められて
いない. 現時点ではGH投与量は血中IGF-I值を年 齢・性別基準範囲内に保たれるように適宜増減 するとされている. IGF-Iの基準内高值が前立腺 癌や乳癌の危険因子の可能性などが論じられて いるので, 血中IGF-Iを基準值の 75percentile より下に維持した方がいいのかどうか今後の課 題である.

\section{おわりに}

最近GHの補充療法が認められた成人GHDにつ いて, 診断と治療のわが国の手引きを中心に概 説した.

尚, わが国の内分泌疾患の診断と治療の手引 きの多くは日本内分泌学会のホームページ (http://square.umin.ac.jp/endocrine/)の診断の 手引きの項に掲載またはそこからリンクしてい るので参照していただきたい.

\section{文献}

1) Rosen $T$, Bengtsson $B A$ : Premature mortality due to cardiovascular disease in hypopituitarism. Lancet 336 : 285$288,1990$.

2) 有田和徳, 他：間脳下垂体腫瘍における成長ホルモン分 泌能 厚生労働科学研究補助金特定疾患対策研究事業間 脳下垂体機能障害に関する調査研究 平成 17 年度総括・ 分担研究報告書 75-79, 2006.

3) Growth Hormone Research Society : Consensus guidelines for the diagnosis and treatment of adults with growth hormone deficiency : summary statement of the Growth Hormone Research Society Workshop on Adult Growth Hormone Deficiency. J Clin Endocrinol Metab 83: 379-381, 1998.

4）千原和夫 : 成人成長ホルモン分泌不全症の診断と治療の 手引き 厚生労働科学研究補助金特定疾患対策研究事業 間脳下垂体機能障害に関する調査研究 平成17年度総括・ 分担研究報告書 121-124, 2006.

5) Molitch ME, et al: Evaluation and treatment of adult growth hormone deficiency : An Endocrine Society clinical practice guideline. J Clin Endocrinol Metab 91 : 16211634, 2006.

6) Tanaka $\mathrm{T}$, et al: A nationwide attempt to standardize growth hormone assays. Horm Res 64(Suppl 2) : 6, 2005. 